\title{
The mobile bag technique as a method for determining the degradation of four botanically diverse fibrous feedstuffs in the small intestine and total digestive tract of ponies
}

\author{
M. J. S. Moore-Colyer ${ }^{1} *$, J. J. Hyslop ${ }^{2} \dagger$, A. C. Longland ${ }^{3}$ and D. Cuddeford ${ }^{2}$ \\ ${ }^{1}$ Institute of Rural Studies, University of Wales Aberystwyth, Llanbadarn Fawr, Aberystwyth SY23 3AL, Ceredigion, Wales, \\ $U K$ \\ ${ }^{2}$ Department of Veterinary Clinical Studies, University of Edinburgh, Easter Bush Veterinary Centre, Roslin EH25 9RG, \\ Midlothian, Scotland, UK \\ ${ }^{3}$ Institute of Grassland and Environmental Research, Plas Gogerddan, Aberystwyth SY23 3EB, Ceredigion, Wales, UK
}

(Received 1 October 2001 - Revised 28 May 2002 - Accepted 15 August 2002)

\begin{abstract}
An in sacco mobile bag technique was used to determine the rate and extent of disappearance of unmolassed sugar-beet pulp, soyabean hulls, hay cubes and an oat hull-naked oats mixture $(67: 33, \mathrm{w} / \mathrm{w})$ in the foregut and total digestive tract of ponies. Ponies were administered naso-gastrically polyester mesh bags $(60 \times 10 \times 10 \mathrm{~mm})$ containing $350 \mathrm{mg}$ feed, in a $3 \times 4$ Latin square design. Bags were collected at the ileo-caecal junction (small intestine bag, SIB) and in the faeces (faecal bag, FB) and their residues analysed for proximate constituents and NSP composition and content. DM disappearances from individual bags were fitted to degradation profiles (Ørskov \& McDonald, 1979) and effective degradability values determined. Significant differences $(P<0.05)$ in $\mathrm{DM}$, organic matter and crude protein $(\mathrm{N} \times 6.25)$ losses from SIB were noted between feeds with hay cubes and oat hulls-naked oats $>$ sugar-beet pulp and soyabean hulls. Acid-detergent fibre, neutral-detergent fibre and NSP disappearances were small and varied little between feeds. In contrast, FB losses showed significant $(P<0.05)$ differences for all constituents measured with sugar-beet pulp $>$ soyabean hulls $>$ hay cubes $>$ oat hulls-naked oats. Crude protein losses from sugar-beet pulp and soyabean hulls in FB were significantly higher $(P<0 \cdot 05)$ than from SIB. FB degradation curves showed degradation to be affected by bag residence time with sugar-beet pulp $>$ soyabean hulls and the effective degradability showed that significantly more $(P<0.05)$ sugar-beet pulp was lost at 40.0 and $60.0 \mathrm{~h}$ than for the other three feeds. These results show that sugar-beet pulp and soyabean hulls are rapidly degraded by ponies and could be used as alternatives to hay in equid rations. However, the foregut availability of crude protein from sugar-beet pulp is poor, so a readily digestible source of crude protein should be offered to animals with high protein demands when diets are based on sugar-beet pulp.
\end{abstract}

Horse: Fibre: Degradation profiles: Effective degradability: Mobile bags

Although horses evolved principally as hindgut fermenters, studies by Gibbs et al. (1988), Peloso et al. (1994) and Coleman et al. (1998) have shown that equids can digest a high proportion of dietary soluble carbohydrates, starch, proteins and fats via enzymatic activity in the small intestine. Performance horse owners, who feed their horses minimal forage and large amounts of cereal-based concentrates, target this foregut digestion in order to meet the energy demands of high-intensity exercise and to keep gut-fill to a minimum (Duren, 1998). While many performance horses require high-starch diets to maximise muscle glycogen stores and fuel anaerobic work (Pagan, 1998), diets containing high levels of cereals, particularly those offered in large infrequent meals, can pre-dispose horses to diet-related metabolic disorders such as acidosis, colic and laminitis (Yelle, 1986; Carroll et al. 1987; Potter et al. 1992). Although horses consuming fibre-based diets are less susceptible to acidosis because fibre maintains

\footnotetext{
Abbreviations: ADF, acid-detergent fibre; CP, crude protein; FB, faecal bag; NDF, neutral-detergent fibre; OM, organic matter; SIB, small intestine bag. * Corresponding author: Dr M. J. S Moore-Colyer, fax +44 1970 611264, email mem@aber.ac.uk

$\dagger$ Current address: Agricultural Development and Advisory Service, Redesdale, Rochester, Otterburn, Newcastle upon Tyne NE19 ISB, UK.
} 
more stable hindgut fermentation variables than cereals (Radicke et al. 1991; Moore-Colyer et al. 2000), the energy from volatile fatty acid metabolism can only be used to fuel extended work due to the limitations of aerobic energy production. Moreover, many traditional fibre-based feeds have apparent digestibility values $<50 \%$ (MooreColyer \& Longland, 2000); thus, the animal is processing a considerable amount of indigestible material. Feeding a more energy-dense fibrous feed could help to alleviate these problems by increasing the proportion of energy derived from the fibrous part of the diet, thereby allowing a moderate reduction in dietary concentrate levels. In addition, some fibrous feeds such as molassed sugar-beet pulp can be a useful source of energy for the performance horse, as it contributes to the glycaemic response and will thus enhance muscle glycogen levels (Groff et al. 2001).

Although a number of workers have examined the total intestinal tract digestibility of different fibrous feeds in horses (Cuddeford et al. 1995; Todd et al. 1995), little information exists on the site and extent of their digestion within the different regions of the gastrointestinal tract. Knowledge of the amount of feed that is digested within a certain region of the gut is particularly useful when considering energy production, as ATP synthesis from glucose metabolism as a result of enzymatic digestion in the small intestine is markedly more efficient than the production of ATP from volatile fatty acid metabolism derived from fibre degradation within the large intestine. Moreover, knowledge of the site of digestion is particularly important when measuring protein availability, as it is only the protein digested in the small intestine that is utilised by the horse (Hintz et al. 1971; Hintz \& Cymbaluk, 1994). Protein, which is fermented in the large intestine, yields $\mathrm{NH}_{3}$, which is synthesised into amino acids by the microbial population (Potter et al. 1992). Although these amino acids are not well utilised by the horse, they are necessary for the growth and maintenance of the hindgut microflora, an essential factor if the fibre component of the diet is to be fully utilised (McDonald et al. 1996).

Currently, most horse and pony diets in the UK are formulated on National Research Council (1989) recommendations, which assume certain digestibility coefficients for energy and protein. However, lack of information on the site of digestion sheds some doubt on the accuracy of these formulations. Studies that determine the amount of dietary energy and protein actually available for metabolism would yield information that could be used to manipulate rations so that they closely match individual animal requirements.

The mobile bag technique has been successfully used in ruminant animals (Kirkpatrick \& Kenelly, 1984; Varvikko \& Vanhatalo, 1990) and pigs (Sauer et al. 1983; Leibholz, 1991) and when used in conjunction with fistulated animals, offers the opportunity to measure both the rate and extent of feed degradation within different segments of the equid gastrointestinal tract (Hyslop et al. 1996; Moore-Colyer et al. 1997; McLean et al. 1999). Such a technique, if combined with effective degradability calculations (Ørskov \& McDonald, 1979), could provide essential results on feed degradation kinetics within the different regions of the equid gut and this information could then be used to improve the accuracy of ration formulation for a wide variety of horses.

The objectives of the experiment reported here were to determine the extent of degradation of four botanically diverse fibrous feeds in the small intestine and total tract of ponies. This, coupled with direct quantitative measurements of dietary NSP content, to overcome the inaccuracies inherent in the detergent methods of fibre analysis (Longland \& Low, 1995), were undertaken with a view to establishing detailed information on the potential nutrient value of four fibrous feeds that could be offered as the basal roughage in the diets of stabled horses.

\section{Materials and methods \\ Experimental design}

Three mature Welsh-cross pony geldings (about $250 \mathrm{~kg}$ live weight), each fitted with a permanent in-dwelling caecal cannula (Cottrell et al. 1998) at the top of the caecum (caecal base), were used in a $3 \times 4$ incomplete Latin square design experiment. Ponies were offered a basal diet of $4 \mathrm{~kg}$ grass nuts $(\mathrm{DM} / \mathrm{d})$, which were soaked in water for $12 \mathrm{~h}$ and given in two equal meals at 09.00 and 17.00 hours. A mineral and vitamin supplement $(30 \mathrm{~g}$; Table 1) was also fed with each meal of grass nuts. Grass hay was available ad libitum from 17.00 to 09.00 hours and water was continuously available from automatic water troughs. The ponies were housed individually in pens and the floor was covered with rubber mats and a small amount of wood shavings.

\section{Preparation of feeds and mobile bags}

The feeds that were placed into the monofilament polyester mesh bags $(60 \times 10 \times 10 \mathrm{~mm})$ were unmolassed sugar-beet pulp (sugar-beet pulp), hay cubes, soyabean hulls and oat hulls-naked oats (67:33, w/w). Disappearances (expressed as coefficients) of DM, organic matter (OM), acid-detergent fibre (ADF), neutral-detergent fibre (NDF), crude protein $(\mathrm{N} \times 6 \cdot 25, \mathrm{CP})$ and NSP were recorded, and individual bag residue disappearances were subsequently calculated according to the formula:

$$
\text { digestibility coefficient }=\frac{I-F}{I},
$$

where $I$ is the amount of feed component $(\mathrm{mg})$ in the bag and $F$ is the amount of the feed component in the bags collected at the caecal fistula or in the faeces (mg).

A portion of each feed $(350 \mathrm{mg})$, ground to pass through a $1 \mathrm{~mm}$ steel-mesh (203 mm laboratory mill; Christy and Norris, Chelmsford, UK) was heat-sealed inside monofilament polyester mesh bags $(60 \times 10 \times 10 \mathrm{~mm}$, pore size $41 \mu \mathrm{m}$; Seriol Ltd, Broadstairs, Kent, UK), using a Packer heat-sealer (model 15/300 H; Viking Direct, Leicester, Leics., UK). The bags were designed according to the recommendations of Macheboeuf et al. (1996), Hyslop \& Cuddeford (1996) and Cherian et al. (1989). In addition, two $100 \mathrm{mg}$ steel washers were sealed into one end of each bag and the bags numbered with indelible pen. The steel washers in the base of the bags allowed 
Table 1. Chemical composition ( $\mathrm{g} / \mathrm{kg} \mathrm{DM})$ of the four experimental feeds and the basal diet

\begin{tabular}{|c|c|c|c|c|c|c|}
\hline \multirow[b]{2}{*}{ Variable } & \multicolumn{4}{|c|}{ Experimental feeds } & \multicolumn{2}{|c|}{ Basal diet† } \\
\hline & Hay cubes & Oat hulls-naked oats* & Unmolassed sugar-beet pulp & Soyabean hulls & Hay & Grass nuts \\
\hline DM & 933 & 900 & 913 & 903 & 827 & 940 \\
\hline OM & 920 & 969 & 903 & 924 & 938 & 907 \\
\hline $\mathrm{CP}$ & 82 & 96 & 78 & 120 & 75 & 146 \\
\hline ADF & 354 & 331 & 271 & 438 & 383 & 365 \\
\hline NDF & 623 & 610 & 547 & 591 & 752 & 623 \\
\hline Total NSP & 378 & 377 & 488 & 492 & - & - \\
\hline Rhamnose & 1 & 0 & 7 & 4 & - & - \\
\hline Arabinose & 29 & 22 & 141 & 37 & - & - \\
\hline Xylose & 102 & 130 & 11 & 45 & - & - \\
\hline Mannose & 4 & 2 & 7 & 35 & - & - \\
\hline Galactose & 13 & 10 & 36 & 20 & - & - \\
\hline Glucose & 209 & 204 & 150 & 261 & - & - \\
\hline Uronic acids & 20 & 9 & 135 & 89 & - & - \\
\hline
\end{tabular}

$\mathrm{OM}$, organic matter, $\mathrm{CP}$, crude protein $(\mathrm{N} \times 6.25)$; ADF, acid-detergent fibre; NDF, neutral-detergent fibre.

*67:33 (w/w).

† Vitamin and mineral supplement $(60 \mathrm{~g} / \mathrm{d})$ was added to the grass nuts: Ca $160 \mathrm{~g} / \mathrm{kg} \mathrm{DM}, \mathrm{P} 117 \mathrm{~g} / \mathrm{kg} \mathrm{DM}, \mathrm{Mg} 67 \mathrm{~g} / \mathrm{kg} \mathrm{DM}, \mathrm{Na} 67 \mathrm{~g} / \mathrm{kg} \mathrm{DM}, \mathrm{Cu} 683 \mathrm{mg} / \mathrm{kg}, \mathrm{Zn}$ $2730 \mathrm{mg} / \mathrm{kg}$, Fe $2730 \mathrm{mg} / \mathrm{kg}$, Mn $2730 \mathrm{mg} / \mathrm{kg}$, I $6.7 \mathrm{mg} / \mathrm{kg}$, Co $6.7 \mathrm{mg} / \mathrm{kg}$.

Vitamin A (palmitate) $7503 \mu \mathrm{g} / \mathrm{kg}$; Vitamin D (cholecalciferol) $0.5 \mathrm{mg} / \mathrm{kg}$; Vitamin E (d, l- $\alpha$-tocophenyl acetate) $3417 \mathrm{mg} / \mathrm{kg}$.

the bags to be captured immediately they passed through the ileo-caecal junction by a specially designed removable magnetic device (Department of Physics, Edinburgh University), which was placed inside the caecal cannula and positioned to lie across the ileo-caecal junction.

\section{Administration of mobile bags}

On two consecutive mornings of each week, twenty bags containing one of the four diets were administered to each pony via a naso-gastric tube. The tube was prefilled with bags before insertion into the nasal passage. Approximately $750-1000 \mathrm{ml}$ water was then pumped into the tube using a hand-operated pump to flush the bags into the stomach. Immediately post- dosing, the magnet was placed inside the caecal cannula to capture bags passing through the ileo-caecal junction. On capture of one or several bags, an electrical circuit inside the magnet was completed and this caused a red light to flash on the external end of the magnet. This indicated to those in attendance that a bag had been caught on the magnet. The cannula top was then opened and the bag(s) immediately removed, before re-positioning of the magnet inside the cannula. The capture time of each bag was noted and the procedure repeated each time a bag was captured, for a period of $8.0 \mathrm{~h}$. Since these bags had passed through the stomach and small intestine only, and were not subjected to any caecal degradation, they were designated small intestine bags (SIB). The magnet was then removed and the remainder of the bags continued through the digestive tract to be recovered in the faeces, and these were termed faecal bags (FB). As soon as the bags were collected (both SIB and FB) they were hand-rinsed in ice-cold water and kept at $40^{\circ} \mathrm{C}$ for a maximum of $2 \mathrm{~h}$, whereupon they were washed using the cold-rinse programme of a domestic washing machine (Indesit model (Italy) 824, programme 5.), according to the procedure described by Hyslop et al. (1999). After drying in a forced-draught oven at $60^{\circ} \mathrm{C}$ for $48 \mathrm{~h}$, individual SIB and
FB bags were weighed to determine the DM losses for each bag. In order to obtain sufficient residue for separate chemical analysis of SIB and FB, the bags were then opened and the contents bulked for each feed within each pony. Thus, results for SIB and FB were obtained for individual bag DM loss for each diet and pony, plus a separate bulked sample of SIB and FB bag residue for each pony and diet, thereby allowing an average value for digestibility of OM, CP $(\mathrm{N} \times 6 \cdot 25), \mathrm{ADF}, \mathrm{NDF}$, total NSP, rhamnose, arabinose, xylose, mannose, glucose and uronic acid to be obtained.

\section{Chemical analysis}

Samples of the four feeds and the bulked residues for both SIB and FB were separately ground using a pestle and mortar and analysed for DM, OM, ADF, NDF, total and individual NSP, starch and $\mathrm{CP}(\mathrm{N} \times 6.25)$ according to the methods of the Association of Official Analytical Chemists (1990).

\section{DM degradation curves}

Within each pony and separately for both SIB and FB results, individual DM disappearances for each feed were subjected to the Ørskov \& McDonald (1979) model (equation 1), which yielded individual pony degradation coefficients and profiles for each feed. The average degradation variables for each feedstuff were then calculated and the degradation profiles described (Figs 1 and 2).

$$
P=a+b\left(1-\mathrm{e}^{-c t}\right),
$$

where $P$ is the degradation after time $t, b$ is the potential degradation of component which will in time be degraded, $c$ is the rate constant for degradation of $b, a$ is the intercept of degradation curve when $t 0$ and e is exponential.

The extent of degradation (effective degradability) was calculated for the FB using equation 2 at the chosen outflow rates of $0.100,0.050,0.025$ and 0.016 , to obtain 

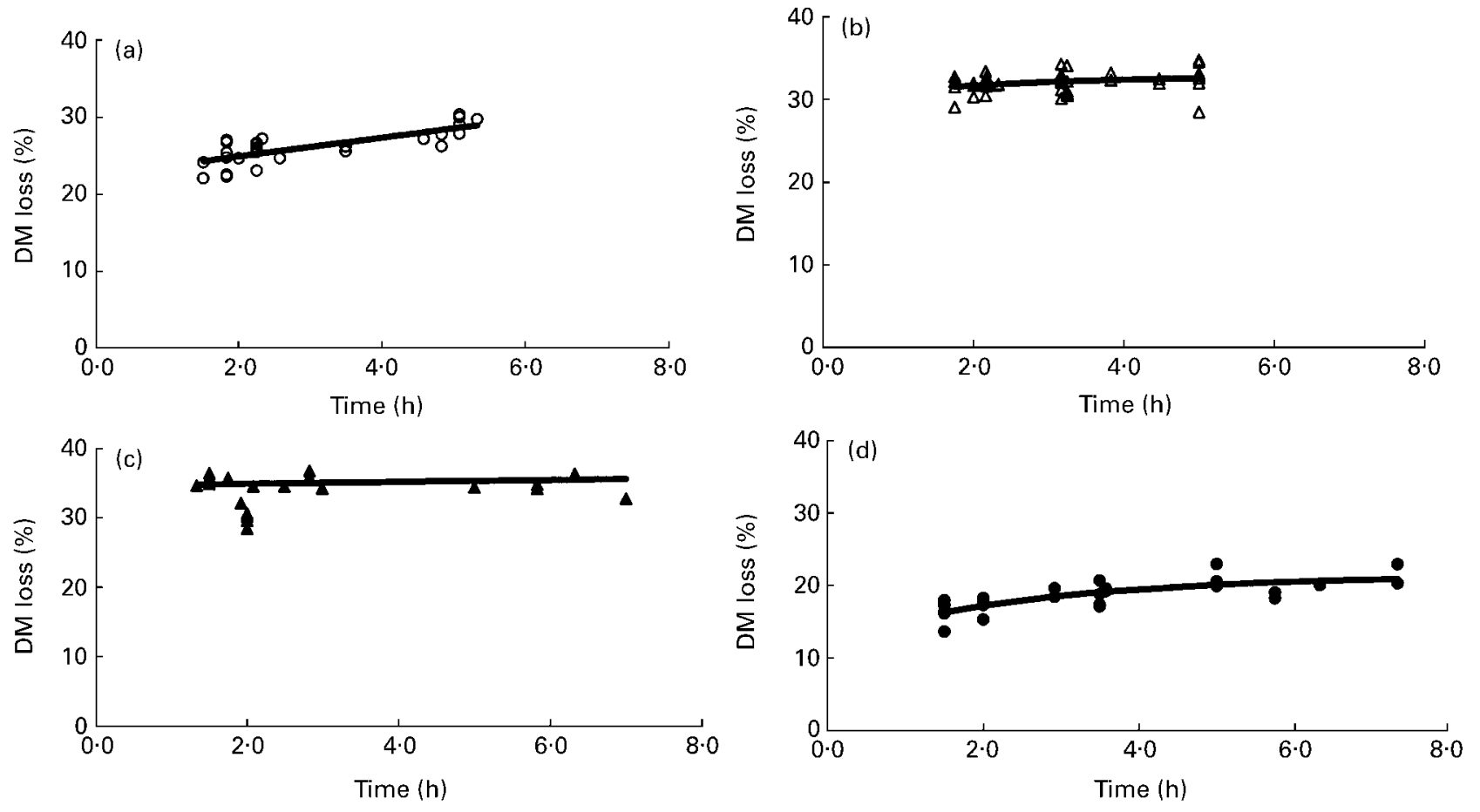

Fig. 1. Disappearance of DM from four feeds contained in polyester mesh bags $(60 \times 10 \times 10 \mathrm{~mm}$, pore size $41 \mu \mathrm{m}$; Seriol Ltd, Broadstairs, Kent, UK), having passed through the small intestine of ponies. (a), Soyabean hulls $\left(R^{2} 0.56\right)$; (b), hay cubes $\left(R^{2} 0.46\right)$; (c), oat hulls-naked oats $\left(R^{2} 0.41\right)$; (d), unmolassed sugar-beet pulp $\left(R^{2} 0.57\right)$. For details of diets and procedures, see p. 730 . Values are means for three ponies. The curves were obtained by the equation of Ørskov \& McDonald (1979; $\left.P=a+b\left(1-\mathrm{e}^{-c t}\right)\right)$ using means values from three ponies.
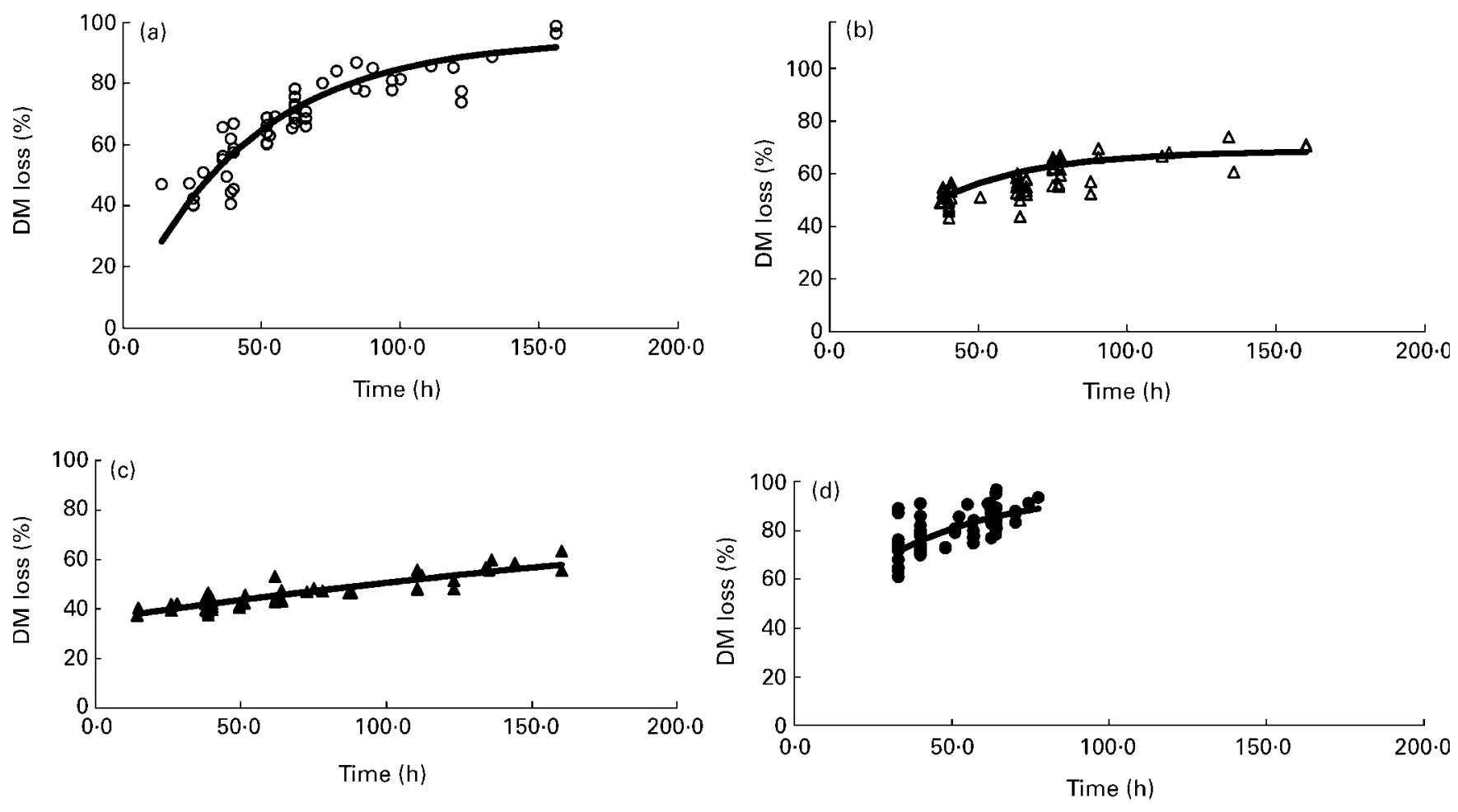

Fig. 2. Disappearance of DM from four feeds contained in polyester mesh bags $(60 \times 10 \times 10 \mathrm{~mm}$, pore size $41 \mu \mathrm{m}$; Seriol Ltd, Broadstairs, Kent, UK), having passed through the total intestinal tract of ponies. (a), Soyabean hulls $\left(R^{2} 0.81\right)$; (b), hay cubes $\left(R^{2} 0.56\right)$; (c), oat hullsnaked oats $\left(R^{2} 0.81\right)$; (d), unmolassed sugar-beet pulp $\left(R^{2} 0.58\right)$. For details of diets and procedures, see p. 730 . Values are means for three ponies. The curves were obtained by the equation of Ørskov \& McDonald $\left(1979 ; P=a+b\left(1-\mathrm{e}^{-c t}\right)\right)$ using means values from three ponies. 
DM loss at the assumed digesta mean retention times of 10.0, 20.0, 40.0 and $60.0 \mathrm{~h}$ :

$$
P=a+\frac{b c}{c+k}
$$

where $k$ is the chosen outflow value.

The degradation at $t 0(a)$, the potential degradation $(b)$, the rate constant $(c), a+b$ and all of the calculated effective degradability values for FB were subjected to a twoway ANOVA using Genstat 5 (1993; Lawes Agricultural Trust, Rothamsted Experimental Station, Harpenden, Herts., UK). The SIB were too few in number to allow a sensible ANOVA to be carried out on individual pony data, thus the SIB data has been presented as the average across all ponies for each feed.

\section{Particle size determination}

The particle size of each of the feedstuffs were determined in a $3 \times 4$ design where $15 \mathrm{~g}$ feed were carefully weighed and placed into the top of a tier of twelve sieves, which ranged in pore size from $40 \mathrm{~mm}$ at the top to $45 \mu \mathrm{m}$ at the base. The cascade of sieves was then placed on an Elf 2000 shaker, which was set to run for $20 \mathrm{~min}$. On completion of the shaking, each sieve was weighed and the following calculation carried out:

$$
\begin{aligned}
& \text { weight of sieve }+ \text { sample }- \text { sieve weight } \\
& \quad=\text { sample weight. }
\end{aligned}
$$

The results obtained were then subjected to the standard procedure for calculating geometric mean particle size (American Dairy Science Association, 1970).

\section{Water-holding capacity}

The water-holding capacity of the three feeds was determined using a modification of the method of Robertson \& Eastwood (1981). Feed (0.5 g) and distilled water $(20.0 \mathrm{ml})$ were placed into $30 \mathrm{ml}$ centrifuge tubes and left to soak at room temperature for $24 \mathrm{~h}$. The tubes were then centrifuged at $5000 \mathrm{rpm}$ for $20 \mathrm{~min}$, whereupon the excess water was decanted and the tube ends raised and left to drain for $1 \mathrm{~h}$. The fresh weight of the feed was determined before oven drying at $60^{\circ} \mathrm{C}$ for $48 \mathrm{~h}$. Sample dry weight was then measured and the water-holding capacity of the feed calculated as $\mathrm{ml}$ water/g feed. This procedure was carried out three times in order to obtain three replicates for each of the four feeds.

\section{Statistical analysis}

All data except the DM degradation coefficients for the SIB were subjected to a two-way ANOVA using Genstat 5 (1993; Lawes Agricultural Trust). Significant differences between feeds for all variables measured were determined using least squares difference tests.

\section{Results}

\section{Feed composition}

The compositions of the experimental feeds are given in Table 1. The DM and OM of the four feeds were similar, but the $\mathrm{CP}(\mathrm{N} \times 6.25)$ content ranged from 78 (sugar-beet pulp) to $120 \mathrm{~g} / \mathrm{kg}$ DM (soyabean hulls). This pattern was paralleled by the ADF contents, but the NDF contents were highest in hay cubes and oat hulls-naked oats at 623 and $610 \mathrm{~g} / \mathrm{kg}$ DM respectively, and lowest in sugarbeet pulp at $547 \mathrm{~g} / \mathrm{kg}$ DM. The total NSP content of sugar-beet pulp and soyabean hulls was about $490 \mathrm{~g} / \mathrm{kg}$ $\mathrm{DM}$, whereas the mean value for hay cubes and oat hulls-naked oats was $100 \mathrm{~g} / \mathrm{kg}$ lower at $380 \mathrm{~g} / \mathrm{kg}$ DM. When calculated as a proportion of the total NSP present, the profile of NSP monomers in hay cubes and oat hullsnaked oats were similar, with $550 \mathrm{~g}$ glucose and $270-300 \mathrm{~g}$ xylose/kg NSP present for both feeds. However, the sugarbeet pulp differed, with $870 \mathrm{~g} / \mathrm{kg}$ total sugar-beet pulp NSP, consisting of near equal proportions of arabinose, glucose and uronic acids, with the levels of arabinose being notably higher than that detected in the other three feeds. The proportions of uronic acids found in sugar-beet pulp and soyabean hulls at 276 and $180 \mathrm{~g}$ uronic acids $/ \mathrm{kg}$ total NSP respectively, were considerably greater than those in the oat hulls-naked oats and hay cubes. Indeed most $(700 \mathrm{~g} /$ $\mathrm{kg}$ NSP) of the soyabean hulls-NSP consisted of uronic acids and glucose in the ratio of about 1:3, and contained comparatively little xylose or arabinose.

\section{Transit time, particle size and water-holding capacity}

Despite significant differences between feeds in waterholding capacity, the transit times of the mobile bags from stomach to caecum averaged $3.3 \mathrm{~h}$, and were not significantly different between feeds (Table 2). The mean

\begin{tabular}{|c|c|c|c|c|c|c|}
\hline Variable & Hay cubes & $\begin{array}{l}\text { Oat hulls-naked } \\
\text { oats }\end{array}$ & $\begin{array}{l}\text { Unmolassed } \\
\text { sugar-beet pulp }\end{array}$ & $\begin{array}{l}\text { Soyabean } \\
\text { hulls }\end{array}$ & SED & $\begin{array}{c}\text { Statistical significance } \\
\text { of effect (ANOVA) }\end{array}$ \\
\hline STT (h) & $3 \cdot 27$ & 2.95 & $4 \cdot 22$ & 2.95 & 0.778 & NS \\
\hline WHC (ml/g DM) & $5 \cdot 10^{a}$ & $2 \cdot 78^{\mathrm{b}}$ & $7 \cdot 31^{c}$ & $5 \cdot 54^{d}$ & 0.160 & * \\
\hline $\mathrm{PS}(\mu \mathrm{m})$ & $247^{a}$ & $369^{b}$ & $430^{\mathrm{b}}$ & $411^{\mathrm{b}}$ & $29 \cdot 0$ & * \\
\hline
\end{tabular}

Table 2. Mobile bag transit time through the small intestine (STT) and through the total tract (TTT), water-holding capacity (WHC) and geometric mean particle size (PS) of hay cubes, oat hulls-naked oats $(67: 33, \mathrm{w} / \mathrm{w})$, unmolassed sugar-beet feed and soyabean hulls $\dagger$

${ }^{a, b, c, d}$ Mean values within the same row with unlike superscript letters were significantly different: $P<0.05$.

${ }^{*} P<0.05$.

†For details of diets and procedures, see Table 1 and p. 730.

$\ddagger$ Polyester mesh bags: $60 \times 10 \times 10 \mathrm{~mm}$; Seriol Ltd, Broadstairs, Kent, UK. 
transit times of the FB were very similar for sugar-beet pulp, hay cubes and oat hulls-naked oats at $65.0 \mathrm{~h}$, whereas the soyabean hulls FB transit time was significantly $(P<0.05)$ lower at $55.0 \mathrm{~h}$. The average particle size of $247 \mu \mathrm{m}$ for hay cubes was significantly $(P<0.05)$ lower than the 369 to $430 \mu \mathrm{m}$ range recorded for the other three feeds. Water-holding capacity was significantly $(P<0.05)$ different between all four feeds with sugar-beet pulp $>$ soyabean hulls $>$ hay cubes $>$ oat hulls-naked oats. The water-holding capacity of sugar-beet pulp was more than $2 \cdot 5$-fold that of oat hulls-naked oats.

\section{Losses from feed in bags passing through the small intestines of ponies}

The losses of nutrients from the bags collected at the caecum (SIB), and those that had travelled through the entire tract (FB), are expressed as coefficients and shown in Table 3. Losses of DM and OM from oat hulls-naked oats and hay cubes SIB were significantly higher than from soyabean hulls, which in turn were greater than from sugar-beet pulp. $\mathrm{CP}(\mathrm{N} \times 6.25)$ losses of 0.77 from oat hulls-naked oats SIB were significantly $(P<0.05)$ higher than the average 0.55 lost from soyabean hulls and hay cubes SIB. Losses of $\mathrm{CP}(\mathrm{N} \times 6.25)$ from sugar-beet pulp SIB at $0 \cdot 30$ were significantly lower than from the other feeds. By contrast, losses of ADF and NDF from SIB were greatest from sugar-beet pulp, followed by hay cubes, soyabean hulls and lastly oat hulls-naked oats, but these differences were only statistically significant $(P<0.05)$ between the sugar-beet pulp and oat hullsnaked oats with losses of $0 \cdot 14$ and $0 \cdot 01$ NDF respectively. Total NSP losses from SIB were not significantly different between the four feeds, although losses from sugar-beet pulp were greater than those from hay cubes and oat hulls-naked oats. Of the major individual NSP components, losses of glucose from oat hulls-naked oats $(0 \cdot 12)$ and of xylose from hay cubes $(0.08)$ were significantly greater $(P<0.05)$ than from the other feeds which showed apparent gains in these constituents. Losses of uronic acids from sugar-beet pulp and soyabean hulls of 0.48 and 0.66 respectively were significantly higher $(P<0.05)$ than from hay cubes and oat hulls-naked oats, there being an apparent gain of 0.35 of uronic acids from the latter. Losses of the minor NSP constituents mannose and galactose from the SIB were greatest from oat hulls-naked oats and hay cubes $>$ soyabean hulls $>$ sugar-beet pulp. There were apparent gains of rhamnose for sugar-beet pulp and soyabean hulls, but losses of this constituent were observed from hay cubes.

Table 3. Disappearances of feed constitutents from hay cubes, oat hulls-naked oats (67:33 w/w), unmolassed sugar-beet pulp and soyabeans hulls contained in polyester mesh bagsł after passing through the small intestine (SIB) and total intestinal tract (FB) of ponies† (Mean coefficients for three ponies)

\begin{tabular}{|c|c|c|c|c|c|c|c|}
\hline Variable & & Hay cubes & $\begin{array}{c}\text { Oat hulls-naked } \\
\text { oats }\end{array}$ & $\begin{array}{l}\text { Unmolassed } \\
\text { sugar-beet pulp }\end{array}$ & $\begin{array}{c}\text { Soyabean } \\
\text { hulls }\end{array}$ & SED & $\begin{array}{c}\text { Statistical significance } \\
\text { of effect (ANOVA) }\end{array}$ \\
\hline DM & SIB & $0.32^{c}$ & $0.34^{c}$ & $0.19^{a}$ & $0.26^{b}$ & & \\
\hline \multirow[t]{2}{*}{ OM } & SIB & $0.29^{c}$ & $0.34^{c}$ & $0 \cdot 18^{a}$ & $0.24^{\mathrm{b}}$ & & \\
\hline & FB & $0.54^{\mathrm{e}}$ & $0.46^{d}$ & $0.87^{\mathrm{g}}$ & $0.67^{f}$ & 0.025 & * \\
\hline \multirow[t]{2}{*}{$\mathrm{CP}$} & SIB & $0.52^{b}$ & $0.77^{\mathrm{e}}$ & $0.30^{a}$ & $0 \cdot 60^{b c}$ & & \\
\hline & FB & $0.62^{\mathrm{bcd}}$ & $0.86^{e}$ & $0.76^{\text {de }}$ & $0.73^{\text {cde }}$ & 0.064 & * \\
\hline & FB & $0.36^{C}$ & $0.21^{b}$ & $0.68^{\mathrm{e}}$ & $0.53^{d}$ & 0.051 & * \\
\hline \multirow[t]{2}{*}{ NDF } & SIB & $0.08^{b}$ & $0.01^{a}$ & $0 \cdot 14^{b c}$ & $0.08^{a b}$ & & \\
\hline & FB & $0.42^{d}$ & $0 \cdot 20^{c}$ & $0.77^{f}$ & $0.56^{\mathrm{e}}$ & 0.035 & * \\
\hline \multirow[t]{2}{*}{ Total NSP } & SIB & $0.05^{a}$ & $0.06^{a}$ & $0 \cdot 13^{a}$ & $0.08^{a}$ & & \\
\hline & FB & $0.57^{c}$ & $0.37^{b}$ & $0.90^{d}$ & $0.64^{c}$ & 0.066 & ** \\
\hline \multirow[t]{2}{*}{ Rhamnose } & SIB & $0.66^{b}$ & $0.00^{\mathrm{a}}$ & $-0.34^{a}$ & $-0.12^{a}$ & & \\
\hline & FB & $0.88^{b}$ & $0.00^{a}$ & $0.94^{b}$ & $0.95^{\mathrm{b}}$ & 0.202 & ** \\
\hline Arabinose & SIB & $0 \cdot 17^{\mathrm{a}}$ & $0.18^{a}$ & $0.12^{\mathrm{a}}$ & $0 \cdot 11^{a}$ & & \\
\hline \multirow[t]{2}{*}{ Xylose } & SIB & $0.08^{a b}$ & $-0.08^{a}$ & $-0.12^{\mathrm{a}}$ & $-0.10^{a}$ & & \\
\hline & FB & $0.46^{\mathrm{cd}}$ & $0.27^{\mathrm{bc}}$ & $0.72^{e}$ & $0.53^{\text {de }}$ & 0.101 & * \\
\hline \multirow[t]{2}{*}{ Mannose } & SIB & $0.54^{b}$ & $0.92^{\mathrm{cd}}$ & $0 \cdot 10^{\mathrm{a}}$ & $0.12^{a}$ & & \\
\hline & FB & $0.86^{c}$ & $1.00^{\mathrm{d}}$ & $0.88^{\mathrm{cd}}$ & $0.93^{\mathrm{cd}}$ & 0.064 & * \\
\hline \multirow[t]{2}{*}{ Galactose } & SIB & $0.34^{\mathrm{b}}$ & $0.32^{b}$ & $0.06^{a}$ & $0 \cdot 19^{a b}$ & & \\
\hline & FB & $0.73^{d}$ & $0.57^{c}$ & $0.97^{e}$ & $0.91^{\mathrm{e}}$ & 0.067 & * \\
\hline \multirow[t]{2}{*}{ Glucose } & SIB & $-0.01^{a b}$ & $0.12^{b}$ & $-0.10^{a}$ & $-0.09^{a}$ & & \\
\hline & FB & $0.55^{c}$ & $0.42^{\mathrm{c}}$ & $0.84^{d}$ & $0.51^{c}$ & 0.088 & * \\
\hline \multirow[t]{2}{*}{ Uronic acids } & SIB & $0.08^{b}$ & $-0.35^{a}$ & $0.48^{\mathrm{cd}}$ & $0.66^{\mathrm{ce}}$ & & \\
\hline & FB & $0.78^{\text {de }}$ & $0.38^{b c}$ & $0.98^{\mathrm{e}}$ & $0.88^{e}$ & 0.180 & * \\
\hline
\end{tabular}

$\mathrm{OM}$, organic matter, $\mathrm{CP}$, crude protein $(\mathrm{N} \times 6.25)$; $\mathrm{ADF}$, acid-detergent fibre; $\mathrm{NDF}$, neutral-detergent fibre. $\mathrm{a}, \mathrm{b}, \mathrm{c}, \mathrm{d}, \mathrm{e}, \mathrm{f}$ Mean values within a row with unlike superscript letters were significantly different $(P<0.05)$. ${ }^{*} P<0.05,{ }^{* \star} P<0.01$.

†For details of diets and procedures, see Table 1 and p. 730.

$\ddagger$ Polyester mesh bags: $60 \times 10 \times 10 \mathrm{~mm}$; Seriol Ltd, Broadstairs, Kent, UK. 
Losses from feed in bags passing through the total tract of ponies

In contrast to the losses of nutrients from the SIB, FB losses showed significant differences between the four feeds for most of the nutrients. For all of the variables measured, the highest losses were recorded for sugar-beet pulp $>$ soyabean hulls $>$ hay cubes $>$ oat hulls-naked oats. More than 0.84 of DM and OM disappeared from the sugar-beet pulp FB. Likewise, in excess of two-thirds of these constituents were lost from soyabean hulls FB and about half of the DM and OM was lost from the hay cubes and oat hulls-naked oats FB. Losses of $\mathrm{CP}(\mathrm{N} \times$ 6.25) from the sugar-beet pulp and soyabean hulls FB were significantly $(P<0.05)$ higher than from their SIB counterparts, this was particularly marked for sugar-beet pulp where $\mathrm{CP}$ losses from FB were $2 \cdot 5$-fold that from the corresponding SIB. The increases in CP losses from the hay cubes and oat hulls-naked oats FB were not significantly greater than from the corresponding SIB. Losses of CP from hay cubes FB were lower than from the other feeds and were significantly $(P<0 \cdot 05)$ lower than $\mathrm{CP}$ losses from the sugar-beet pulp and oat hullsnaked oats FB. Losses of ADF and NDF from the FB for all feeds were significantly $(P<0.05)$ higher than from the corresponding SIB, and losses of these components were significantly $(P<0.05)$ different for each feed, with highest losses being recorded from sugar-beet pulp FB of 0.68 and 0.77 for $\mathrm{ADF}$ and NDF respectively. Lowest losses were recorded from oat hulls-naked oats, with $\mathrm{ADF}$ and NDF disappearances averaging 0.21. Losses of total NSP from FB of each feed were higher than those losses from the SIB. Loss of total NSP from sugar-beet pulp FB was 0.90 which was significantly $(P<0.01)$ higher than that from hay cubes and soyabean hulls, which averaged 0.60 ; these losses were significantly $(P<0.05)$ higher than the 0.37 lost from oat hulls-naked oats. Losses of the major NSP monomers (glucose, arabinose, uronic acids and xylose) from sugar-beet pulp FB all exceeded 0.72 and apart from the uronic acids; these losses were significantly $(P<0.05)$ greater than from the other feeds, whereas losses of these nutrients from oat hulls-naked oats FB were less than 0.48 , significantly $(P<0.05)$ lower than the corresponding losses from the other feeds. Losses of the major NSP monomers from soyabean hulls and hay cubes FB were not significantly different from each other. The losses of the minor NSP constituents, rhamnose, mannose and galactose from the FB were higher than 0.73 from all feeds except for oat hulls-naked oats, from which no net losses of rhamnose occurred and where losses of galactose averaged 0.57 .

\section{Fitted DM degradations}

Fitted Ørskov \& McDonald (1979) DM degradation curves from the three ponies for each feed are shown in Figs 1 and 2. Fig. 1 shows the average small intestine (SIB) curves for each feed and the individual bag DM values collected from each pony at the ileo-caecal junction, while Fig. 2 shows the average total tract curves for each feed and the individual faecal bag DM values collected from each pony.
For all feeds tested, bags were retrieved from the caecal cannula over the period $1.5-8.0 \mathrm{~h}$ and lost only $0 \cdot 15-$ 0.35 of DM. Fitted results from the FB suggested that degradation was markedly affected by bag residence time in the large intestine. In excess of 0.65 disappeared from sugar-beet pulp when bags were incubated for $40.0 \mathrm{~h}$, whereas soyabean hulls and hay cubes disappearances only reached this level after $60.0 \mathrm{~h}$ incubation. Oat hullsnaked oats lost a maximum of 0.58 after $16.0 \mathrm{~h}$ in the digestive tract. Although after $14.0 \mathrm{~h}$ of incubation sugarbeet pulp and soyabean hulls did lose more than $90 \%$ $\mathrm{DM}$, the speed at which these disappearances occurred in the earlier stages of incubation were significantly $(P<0.05)$ different: sugar-beet pulp attainined $70 \%$ degradation in $30.0 \mathrm{~h}$, whereas it took over $60.0 \mathrm{~h}$ for soyabean hulls to reach $70 \%$. The calculated effective degradability of each feed detailed in Table 4 indicate that the longer the incubation time, the greater the difference between feeds, with sugar-beet pulp being significantly $(P<0.05)$ more degraded than the other three feeds at 40.0 and $60.0 \mathrm{~h}$ mean residence time, whereas the shorter incubation of $10.0 \mathrm{~h}$ shows no significant differences between any of the feeds on mean retention time.

\section{Discussion}

\section{Feed composition}

The NSP content and composition of the feeds derived from the Graminaea (hay cubes and oat hulls-naked oats) were similar to those reported in other studies, (Longland \& Low, 1989; Bach-Knudsen, 1991). However, although the monomeric composition of the NSP fractions of the sugar-beet pulp and soyabean hulls used here were similar to those found elsewhere, (Longland \& Low, 1989), the total NSP contents of these feeds were somewhat lower than the $600 \mathrm{~g} / \mathrm{kg}$ DM for sugar-beet pulp reported by Graham et al. (1986), Bach-Knudsen (1991) and Longland \& Low (1988) and 621-840 g/kg DM for soyabean hulls found by Longland \& Low (1988). These differences probably reflect varying efficiencies in the industrial extraction of sucrose from sugar beet on the one hand and the de-hulling of soyabeans on the other. $\mathrm{CP}(\mathrm{N} \times 6.25)$ contents of sugar-beet pulp, soyabean hulls and oat hulls-naked oats were similar to those found in other studies by Moore-Colyer (2000) and (MJS MooreColyer and AC Longland, unpublished results). The hay cubes used in the present study had lower ADF and NDF contents and had twice the amount of $\mathrm{CP}(\mathrm{N} \times 6.25)$ than that found in the long hay used by Moore-Colyer \& Longland (2000). This indicates than the hay cubes contained grass conserved at an earlier stage of growth and was thus of a higher nutrient quality than traditionally made grass hay.

\section{Loss of particles from mobile bags}

The bags used in the present study conformed to the recommendations for using mobile bags in equids (Macheboeuf et al. 1996). These recommendations advise that: particles inside the bag should be approximately $1.5 \mathrm{~mm}$ 
Table 4. Variables in the DM degradation curve effective degradability (ED) values calculated for $10 \cdot 0,20.0,40.0$ and $60.0 \mathrm{~h}$ mean retention time for hay cubes, oat hulls-naked oats $(67: 33, \mathrm{w} / \mathrm{w})$, unmolassed sugar-beet pulp and soyabean hulls determined from residues contained in polyester mesh bags $\ddagger$ after passing through the small intestine (SIB) and total tract of ponies (FB)†

\begin{tabular}{|c|c|c|c|c|c|c|}
\hline & Hay cubes & $\begin{array}{c}\text { Oat hulls-naked } \\
\text { oats }\end{array}$ & $\begin{array}{l}\text { Unmolassed } \\
\text { sugar-beet pulp }\end{array}$ & $\begin{array}{l}\text { Soyabean } \\
\text { hulls }\end{array}$ & SED & $\begin{array}{l}\text { Statistical significance } \\
\text { of effect (ANOVA) }\end{array}$ \\
\hline \multicolumn{7}{|l|}{ SIB } \\
\hline$a$ & 29.7 & 34.7 & $12 \cdot 0$ & 22.4 & $\mathrm{~N} / \mathrm{C}$ & - \\
\hline$b$ & 2.9 & $65 \cdot 3$ & $9 \cdot 1$ & $77 \cdot 6$ & $\mathrm{~N} / \mathrm{C}$ & - \\
\hline$c$ & 0.52 & 0.002 & 0.42 & 0.02 & $\mathrm{~N} / \mathrm{C}$ & - \\
\hline$a+b$ & $32 \cdot 7$ & 100 & $21 \cdot 1$ & 100 & $\mathrm{~N} / \mathrm{C}$ & - \\
\hline \multicolumn{7}{|l|}{ FB } \\
\hline$a$ & $12 \cdot 3$ & $35 \cdot 7$ & $36 \cdot 8$ & 4.2 & $25 \cdot 54$ & NS \\
\hline$b$ & $66 \cdot 9$ & $63 \cdot 1$ & $60 \cdot 1$ & 90.4 & 17.98 & NS \\
\hline$c$ & 0.031 & 0.003 & 0.026 & 0.022 & 0.0194 & NS \\
\hline$a+b$ & $79 \cdot 2$ & 98.7 & $96 \cdot 8$ & 94.6 & $11 \cdot 28$ & NS \\
\hline \multicolumn{7}{|l|}{ ED (\%)§ } \\
\hline $10.0 \mathrm{~h}$ & $27 \cdot 6$ & 37.30 & $50 \cdot 6$ & 20.5 & 14.62 & NS \\
\hline $20.0 \mathrm{~h}$ & $35 \cdot 0^{\mathrm{ab}}$ & $38.9^{\mathrm{ab}}$ & $58 \cdot 7^{b}$ & $31 \cdot 7^{\mathrm{a}}$ & $10 \cdot 25$ & * \\
\hline $40.0 \mathrm{~h}$ & $43 \cdot 1^{\mathrm{a}}$ & $41.8^{\mathrm{a}}$ & $68 \cdot 1^{\mathrm{b}}$ & $46 \cdot 1^{a}$ & $6 \cdot 80$ & * \\
\hline $60.0 \mathrm{~h}$ & $47 \cdot 9^{\mathrm{a}}$ & $44.4^{\mathrm{a}}$ & $73 \cdot 6^{\mathrm{b}}$ & $55 \cdot 0^{\mathrm{a}}$ & 5.57 & * \\
\hline
\end{tabular}

$a$, Degradation at time zero; N/C, not calculated, $b$, potentially degradable material; $c$ rate constant for degradation of $b$.

$\mathrm{a}, \mathrm{b}$ Mean values within a row with unlike superscript letters were significantly different $(P<0.05)$

${ }^{*} P<0.05$.

†For details of diets and procedures, see Table 1 and p. 730.

$\ddagger$ Polyester mesh bags: $60 \times 10 \times 10 \mathrm{~mm}$; Seriol Ltd, Broadstairs, Kent, UK.

$\S \mathrm{ED}=a+b c / c+k$ (Ørskov \& McDonald, 1979), where $k$ is the chosen outflow value.

in size; sample weight to bag surface area should be $1 \mathrm{mg} / \mathrm{mm}^{2}$ and bag pore size should be $40-60 \mu \mathrm{m}$. These recommendations ensure that microbial colonisation and free exchange of fluid occurs between the bag and gut contents. In addition, this pore size should allow passage of fermentation end products to occur from the bag and small-undegraded particles to be retained within in the bag, while small particles from the basal diet are prevented from entering the bag. These recommendations are widely accepted by ruminant animal (Uden \& Van Soest, 1984; Cockburn et al. 1993; Huntington \& Givens, 1995) and pig (Cherian et al. 1989) nutritionists to give similar results to conventional digestibility studies, and although limited mobile bag studies have been carried out in equids, the work of Macheboeuf et al. (1996) indicates that these guidelines are also appropriate for in sacco work in equids.

Washing the retrieved bags using the rinse programme of an automatic washing machine is also a recommended procedure and is designed to remove mucous, endogenous enzymes and microbial biomass from the feed residue (Van Straalen et al. 1993). In the present experiment, three replicates of the feed samples were subjected to the rinse programme of a domestic washing machine (washing machine bags) in order to assess the effect of cold-water washing on particle loss. Hay cubes and oat hulls-naked oats lost approximately $24 \% \mathrm{DM}$ and between 20 and $59 \% \mathrm{CP}(\mathrm{N} \times 6 \cdot 25)$, whereas sugar-beet pulp and soyabean hulls lost less than $10 \%$ of both these nutrients. Fibre losses measured by NSP analysis, were lower, with only $4 \%$ removed from soyabean hulls and sugar-beet pulp and $15 \%$ from oat hulls-naked oats and hay cubes. Although Van Straalen et al. (1993) and Macheboeuf et al. (1996) both stressed the importance of an intensive wash to remove mucous, enzymes and microbes from the feed residue, it would appear from this experiment that such treatment also dispatched some of the soluble feed material, particularly the $\mathrm{CP}(\mathrm{N} \times 6.25)$ present in the naked oats portion of the oat hulls-naked oats mix, of which $59 \%$ was lost. However, the washing machine bags had not passed through an enzymatic digestion process, and as is shown by Potter et al. (1992) and by the results of the present experiment, $\mathrm{CP}$ in cereals is readily digested by enzymatic action in the equid foregut; thus, the washing of the bags after passage through the gut would have had a minimal effect on the CP disappearance values. However, some particle loss as a result of coldwater washing was clearly evident, as the hay cubes and oat hulls-naked oats lost $15 \%$ of the insoluble NSP fraction. Although machine washing ensures a standardised washing procedure, the process, particularly the 'spinning' aspect, may cause excessive loss of small particles from the bags, which a more gentle hand-wash could avoid. Moreover, the NSP analytical procedure results in the removal of protein, lipids, endogenous $\mathrm{N}$ and microbial $\mathrm{N}$ through the use of pancreatic enzymes (Longland \& Low, 1989). Therefore, if NSP analysis were the method of choice for determining the fibre content of feedstuffs, there would be no need for such rigorous post-incubation washing.

\section{Particle size, transit time and water-holding capacity}

The hay cubes and oat hulls-naked oats respectively had significantly $(P<0 \cdot 05)$ and non-significantly smaller geometric mean particle sizes than either sugar-beet pulp or soyabean hulls. However, the DM losses recorded in the present experiment are unlikely to be due to physical loss of undegraded particles from the bags as soyabean hulls (with a mean particle size $122 \mu \mathrm{m}$ greater than hay cubes) lost slightly more DM on passing through the small intestine than the hay cubes. The DM disappearances noted from the FB also appears to be less influenced by 
particle size than the processes of digestion and fermentation, as sugar-beet pulp had the largest mean particle size, yet the highest DM losses, whereas hay cubes had the smallest particle size but significantly $(P<0.05)$ lower DM loss than both sugar-beet pulp and soyabean hulls.

The mean transit times of the FB through the gastrointestinal tract of the ponies in the present study, which ranged from 55.0 to $65.0 \mathrm{~h}$ for all feeds tested, were nearly twice as long as the 31.0 and $32.9 \mathrm{~h}$ reported by Macheboeuf et al. (1996) and Tomlinson (1997) respectively. This difference may be due to the metal washers that were sealed into one end of the bags, thus making them heavier than those used by Macheboeuf et al. (1996). The increased weight may have resulted in the bags sinking to the gut floor, thereby reducing their passage rate through the gut. Although the water-holding capacity of the feeds differed, this did not substantially affect passage rate as bags containing soyabean hulls had a faster passage rate than those containing sugar-beet pulp or hay cubes, which had higher and lower water-holding capacity respectively than soyabean hulls.

\section{Fitted DM degradations}

The major benefit of the mobile bag technique over total collection studies is the potential for obtaining information on both the rate and extent of feed degradation. The wide range of recovery times for both the SIB and FB (Figs 1 and 2) meant that feed had effectively been incubated for 1.5 to $7.5 \mathrm{~h}$ in the small intestine and 14.0 to $150 \mathrm{~h}$ in the large intestine. The average degradation profiles (Ørskov \& McDonald, 1979), fitted to the losses recorded from the SIB (Fig. 1), show oat hulls-naked oats to lose a one-third of DM present within the first $2.0 \mathrm{~h}$ of incubation, whereas the sugar-beet pulp lost less than a quarter of DM after $7.0 \mathrm{~h}$ of incubation. This situation was reversed in the FB (Fig. 2), which clearly shows that sugar-beet pulp and soyabean hulls were not only more fully degraded, but were also more rapidly degraded than oat hulls-naked oats. The mobile bag technique therefore yields precise information on the availability of nutrients within the different regions of the gastrointestinal tract and can be used to increase the precision of matching nutrient supply to individual animal requirements. Furthermore, the Ørskov \& McDonald (1979) model allows effective degradability values to be calculated by taking account of the passage rate of digesta through the tract and so allows the nutrient value of a feed to be determined for different mean retention times (Table 4). Although the average mean retention times within the total tract were similar for hay cubes, oat hulls-naked oats and sugarbeet pulp, the soyabean hulls FB were retained within the total tract of the ponies for $10.0 \mathrm{~h}$ less, so the end point digestibility values obtained from the bulked FB samples were confounded with residence time. Thus, the only accurate way to compare across feeds is to calculate effective degradability values for a given residence time. Thus, a true comparison between feeds, e.g. sugar-beet pulp and soyabean hulls, can be done for a meaningful retention time such as $20.0 \mathrm{~h}$, which shows that sugarbeet pulp was significantly more degraded than soyabean hulls. Combinations of foregut and hindgut degradation profiles thus have considerable potential for improving ration formulation for horses, as selection of feedstuffs can be done on the basis of nutrient content, potential digestibility and rate of digestion within different regions of the gastrointestinal tract.

\section{Losses of fibre from feed in bags passing through the small intestine and total tract of ponies}

The results of the present study indicate that fibre composition had a greater influence on degradability in both the small intestine and total tract of ponies than the time the feed remained within the gastrointestinal tract. Despite the significantly $(P<0.05)$ lower total transit time for soyabean hulls $(54.0 \mathrm{~h})$ compared with sugar-beet pulp and hay cubes $(65.0 \mathrm{~h})$ the recorded disappearances for all monomers except glucose were greater for soyabean hulls than those recorded for hay cubes.

The highest and lowest losses of fibre from both the SIB and FB were from sugar-beet pulp, and oat hulls-naked oats respectively, and although the bags had a longer mean retention time than 'free digesta' within the gastrointestinal tract, the disappearance values correspond closely with the digestibility values for these feeds recorded in an earlier total collection trial (Moore-Colyer, 2000). The main constituent of sugar-beet pulp is fibre (Table 1) and the $78 \mathrm{~g} \mathrm{CP}(\mathrm{N} \times 6 \cdot 25) / \mathrm{kg} \mathrm{DM}$ in this feed is largely cell-wall bound; thus, the FB DM degradation curves largely reflect the disappearance of the fibre fraction in sugar-beet pulp. Thus, the end point total NSP disappearance and the DM degradation curves for sugar-beet pulp indicate that this feed was not only more degradable, but was more rapidly degraded than the fibre fractions of the other three feeds. These observations concur with the earlier findings (Stefánsdóttir, 1996; Hyslop et al. 1999), where the in situ technique was used in caecally fistulated ponies to measure the speed and extent of degradation of fibrous feedstuffs similar to those used in the present study. The variations in the rates and extents of feedstuff degradation may, at least in part, be attributed to differences in the composition of their fibrous fractions. Approximately two-thirds of the sugar-beet pulp NSP was composed of arabinose and uronic acids, both of which are known to be highly degradable (Van Soest, 1994). By contrast, the poor degradability of the oat hulls - naked oats noted in the present study and by Stefánsdóttir (1996) and Hyslop et al. (1999) may be attributed to high NSP contents of cellulosic glucose and xylose, NSP fractions that are known to be particularly resistant to microbial action (Graham et al. 1986). Although soyabean hulls and hay cubes both contained considerable amounts of cellulosic glucose, the soyabean hulls contained substantially lower levels of xylose, and this may well account for the more rapid and extensive degradation of this feed compared with that of hay cubes within the total tract of ponies.

The maximum and minimum pre-caecal losses of NSP expressed as a proportion of total NSP losses from FB (Table 5), were $15 \%$ for sugar-beet pulp and $9 \%$ for hay cubes. These low levels of pre-caecal degradation of sugar-beet pulp NSP are in contrast to those reported for 
Table 5. Pre-caecal disappearance of hay cubes' oat hulls-naked oats (67:33, w/w), unmolassed sugar-beet pulp and soyabean hulls from polyester mesh bagsł collected at the ileo-caecal junction, expressed as a proportion of total intestinal tract disappearances determined from corresponding bags that had passed through the total intestinal tract of poniest

(Mean coefficients for three ponies)

\begin{tabular}{|c|c|c|c|c|c|c|}
\hline & Hay cubes & $\begin{array}{c}\text { Oat hulls-naked } \\
\text { oats }\end{array}$ & $\begin{array}{l}\text { Unmolassed } \\
\text { sugar-beet pulp }\end{array}$ & $\begin{array}{c}\text { Soyabean } \\
\text { hulls }\end{array}$ & SED & $\begin{array}{c}\text { Statistical significance } \\
\text { of effect (ANOVA) }\end{array}$ \\
\hline DM & $0.57^{b}$ & $0.75^{d}$ & $0.22^{a}$ & $0.38^{c}$ & 0.033 & $\star \star$ \\
\hline $\mathrm{CP}$ & $0.85^{b}$ & $0.90^{\mathrm{b}}$ & $0.39^{a}$ & $0.82^{b}$ & 0.088 & ** \\
\hline ADF & 0.37 & 0.22 & 0.16 & 0.14 & 0.122 & NS \\
\hline NDF & 0.20 & 0.02 & 0.18 & 0.14 & 0.140 & NS \\
\hline Total NSP & 0.09 & 0.10 & 0.15 & 0.14 & $0 \cdot 171$ & NS \\
\hline Arabinose & $0 \cdot 26^{a b}$ & $0.36^{b}$ & $0.12^{\mathrm{a}}$ & $0 \cdot 14^{a}$ & 0.080 & * \\
\hline Xylose & 0.21 & -0.14 & -0.16 & -0.19 & 0.380 & NS \\
\hline Mannose & $0.63^{b}$ & $0.92^{c}$ & $0.11^{a}$ & $0.13^{a}$ & 0.093 & $\star \star$ \\
\hline Galactose & $0.43^{b}$ & $0.56^{\mathrm{b}}$ & $0.06^{a}$ & $0.21^{a}$ & 0.091 & * \\
\hline Glucose & $-0.03^{a b}$ & $0 \cdot 27^{b}$ & $-0 \cdot 14^{a}$ & $-0.17^{a}$ & 0.147 & * \\
\hline Uronic acids & $0 \cdot 10^{\mathrm{ab}}$ & $-0.79^{b}$ & $0.49^{\mathrm{a}}$ & $0.74^{a}$ & 0.367 & * \\
\hline
\end{tabular}

$\mathrm{OM}$, organic matter, $\mathrm{CP}$, crude protein $(\mathrm{N} \times 6.25)$; $\mathrm{ADF}$, acid-detergent fibre; $\mathrm{NDF}$, neutral-detergent fibre.

$\mathrm{a}, \mathrm{b}, \mathrm{c}$ Mean values within a row with unlike superscript letters were significantly different $(P<0.05)$.

${ }^{\star} P<0.05,{ }^{* *} P<0.01$

†For details of diets and procedures, see Table 1 and p. 730

$\ddagger$ Polyester mesh bags: $60 \times 10 \times 10 \mathrm{~mm}$; Seriol Ltd, Broadstairs, Kent, UK.

pigs, where more than $300 \mathrm{~g}$ sugar-beet pulp NSP/kg disappeared in the small intestine (Longland \& Low, 1989). This suggests that the level of pre-caecal microbial activity in ponies is limited in comparison to that of growing pigs, or that the small intestinal feed residence time is lower in ponies compared with pigs. In the current study, of the individual NSP monomers present in significant quantities, it was the uronic acid and arabinose that disappeared most readily, whereas there were apparent gains of xylose and glucose in most cases. These gains were probably due to ingress, into the bags, of feed particles derived from the basal diet. However, ingress of particles into the bags is unlikely to explain why more ADF than NDF disappeared from the hay cubes SIB. Theoretically, ADF analysis measures the cellulose and lignin content after boiling with acid-detergent solution, but the system has several flaws (Morrison, 1980). The empirical nature of the analysis means that the end result is obtained by calculation of what is left after repeated boiling with detergent solutions, rather than measuring what the sample contains per se. In addition, the ADF fraction may not contain just cellulose and lignin, but may incorporate matrix polysaccharides as well as structural polysaccharides, while the accuracy of the NDF analysis can be compromised by the solubilisation in neutral-detergent solution of important cell wall constituents such as pectins (Southgate et al. 1978; Theander \& Aman, 1979; Morrison, 1980); thus, these anomalies could easily account for the $5 \%$ discrepancy between the ADF and NDF disappearances.

Losses of organic matter and crude protein $(N \times 6 \cdot 25)$ from feed in bags passing through the small intestine and total gastrointestinal tract of ponies

The significant difference in DM and OM losses from the four feeds in SIB can be attributed to losses in $\mathrm{CP}(\mathrm{N} \times$
6.25) and other unmeasured nutrients such as water-soluble carbohydrates, as none of the losses of total NSP from the feeds were significantly different. The $54 \%$ loss of OM from hay cubes FB was similar to the $56 \%$ reported by Smoulders et al. (1990) for grass hay fed to horses, and the $87 \%$ loss of OM from sugar-beet pulp FB reflects the highly degradable nature of this feed, and is very close to the $85-90 \%$ noted in pigs by Graham et al. (1986), Longland \& Low (1988) and Yan et al. (1995).

The particularly high level of $\mathrm{CP}(\mathrm{N} \times 6.25)$ loss from the oat hulls - naked oats reflects the botanical origin of the protein in this feed. Cereal CP is known to be digested well in the equid small intestine (Gibbs et al. 1996), whereas a greater proportion of the protein in fibrous feeds is degraded in the large intestine. Clearly, this is an important consideration when formulating rations for horses with high protein demands, as only protein digested in the small intestine can be utilised by the horse (Hintz \& Cymbaluk, 1994). In the present study, only $30 \%$ sugarbeet pulp $\mathrm{CP}$ and $52 \%$ hay cube $\mathrm{CP}$ were degraded in the small intestine, which are equivalent in quantitative terms to less than one-third and one-half respectively of the protein provided by the oat hulls-naked oats diet. However, although the extent of $\mathrm{CP}$ loss from hay cubes FB remained lower than from oat hulls-naked oats FB, CP loss from the sugar-beet pulp FB was not significantly different from the oat hulls-naked oats FB. Sugar-beet pulp contains a hydroxyproline-rich fraction within the cell wall, which may have been unavailable to proteolytic action in the small intestine, but became available in the large intestine as the NSP fraction was progressively fermented. Although $15 \%$ of the total NSP was lost from SIB this was clearly insufficient to release the majority of the protein. These results serve to illustrate the shortcomings of using total tract $\mathrm{CP}$ digestibility values in ration formulation in horses, for the relative contributions 
of small intestine digestion and large intestinal fermentation to overall protein degradation are unknown and vary with botanical origin of the feed. Therefore use of total tract CP digestibility values may either lead to horses being protein deficient, or to animals being fed excess protein, which is both wasteful and potentially harmful.

\section{Conclusion}

Results from the present experiment demonstrate that the mobile bag technique can be used to determine the apparent digestibility of botanically diverse fibrous feeds in ponies. Use of this technique in fistulated ponies allowed feedstuff degradation to be measured within different segments of the digestive tract and hence improve current knowledge on nutrient availability in the horse. In addition, in sacco techniques allow effective degradabilities to be calculated, which is particularly useful information when manipulating diets for performance horses engaged in activities that require both rapid and sustained energy release. Thus, the feed that yielded the most nutrients in the total tract of the ponies was sugar-beet pulp $>$ soyabean hulls $>$ hay cubes $>$ oat hulls-naked oats. Sugarbeet pulp was also found to be the most rapidly degraded feed in the total tract, but its digestibility in the foregut was limited, particularly with regard to $\mathrm{CP}(\mathrm{N} \times 6 \cdot 25)$. Although soyabean hulls were also readily degraded after prolonged residence in the gut, normal digesta mean retention times of about $36.0 \mathrm{~h}$ indicate that when energy intake is at a premium, sugar-beet pulp should be the feed of preference. However, as demonstrated in the present experiment, sugar-beet pulp and hay cubes were both poor sources of available CP, so diets for equids with high protein demands should include adequate amounts of feedstuffs such as cereals or soyabean hulls. These supply small intestinal digestible protein and can therefore be utilised by the horse.

\section{Acknowledgements}

We would like to thank D. H. Anderson and T. McHale for care of the animals, B. L. M. McLean for assistance during the experimental work, R. Leyton and R. Murihead for laboratory analysis and M. S. Dhanoa for statistical advice. This work was part of Project 612 supported by the Horserace Betting Levy Board.

\section{References}

American Dairy Science Association (1970) A report: committee on classification of particle size in feedstuffs. Journal of Dairy Science 53, 689-690.

Association of Official Analytical Chemists (1990) Official Methods of Analysis of the Association of Official Analytical Chemists, 15th ed. Arlington, VA: AOAC.

Bach-Knudsen E (1991) Gastrointestinal implications in pigs of wheat and oat dietary fibre, (2) Microbial activity in the gastrointestinal tract. British Journal of Nutrition 65, 233-248.

Caroll CL, Hazard G, Coloe PJ \& Hooper PT (1987) Laminitis and possible enterotoxaemia associated with carbohydrate overload in mares. Equine Veterinary Journal 19, 344-346.
Cherian G, Sauer WC \& Thacker PA (1989) Factors affecting the apparent digestibility of protein for swine when determined by the mobile nylon bag technique. Animal Feed Science and Technology 27, 137-146.

Cockburn J, Dhanoa MS, France J \& Lopez S (1993) Overestimation of solubility when using dacron bag methodology. Animal Production 56, 466-467.

Coleman RJ, Mathison GW, Ingram J \& Bell D (1998) Cannulation of the distal ileum in ponies. Canadian Journal of Animal Science 78, 445-447.

Cottrell DF, Jones AJ \& Potter KE (1998) Gas handling in the caecum of the horse. Experimental Physiology 83, 397-408.

Cuddeford DC, Pearson RA, Archibalb RF \& Muirhead RH (1995) Digestibility and gastrointestinal transit time of diets containing different proportions of alfalfa and oat straw given to Thoroughbreds, Shetland ponies, Highland ponies and donkeys. Animal Science 61, 407-417.

Duren SE (1998) Feeding the endurance horse. In Advances in Equine Nutrition, [JD Pagan, editor]. Trowbridge, Wilts.: Nottingham University Press.

Gibbs PG, Potter GD, Schelling GT, Kreider JL \& Boyd CL (1988) Digestion of hay protein in different segments of the equine digestive tract. Journal of Animal Science 66, 400-406.

Gibbs PG, Potter GD, Schelling GT, Kreider JL \& Boyd CL (1996) The significance of small vs. large intestine digestion of cereal grain and oil seed protein in the equine. Journal of Equine Veterinary Science 16, 60-65.

Graham H, Hesselman K \& Aman P (1986) The influence of wheat bran and sugar beet pulp on the digestibility of dietary components in a cereal based pig diet. Journal of Nutrition 116, 242-251.

Groff L, Pagan J, Hoekstra K, Gardner S, Rice O, Roos K \& Geor $\mathrm{R}$ (2001) Effect of preparation method on the glycaemic response to ingestion of beet pulp in Thoroughbred horses. Proceedings of the Equine Nutrition and Physiology Society, Kentucky. Savoy, WA: ENPS.

Hintz HF, Argenzio RA \& Schyrver HF (1971) Digestibility coefficients, blood glucose levels and molar percentages of volatile fatty acids in intestinal fluid of ponies fed varying forage-grain ratios. Journal Animal Science 33, 992-995.

Hintz HF \& Cymbaluk NF (1994) Nutrition of the horse. Annual Review of Nutrition 14, 243-267.

Huntington JA \& Givens DJ (1995) The in situ technology for studying the rumen degradation of feeds: A review of the Procedure. Nutrition Abstracts and Reviews 65, 63-93.

Hyslop JJ \& Cuddeford DC (1996) Investigations on the use of the mobile bag technique in ponies. Animal Science 62, 647 Abstr.

Hyslop JJ, Stefánsdóttir GJ, McLean BML, Longland AC \& Cuddeford DC (1999) In situ incubation sequence and its effect on degradation of feed components when measured in the caecum of ponies. Animal Science 69, 147-157.

Kirkpatrick BK \& Kennelly JJ (1984) Prediction of digestibility in cattle using a modified nylon bag technique. Canadian Journal of Animal Science 64, 1104.

Leibholz J (1991) A rapid assay for the measurement of protein digestion to the ileum of pigs by the use of a mobile nylon bag technique. Animal Feed Science and Technology 33, 209-219.

Longland AC \& Low AG (1995) Prediction of the energy value of alternative feeds for pigs. In Recent Advances in Animal Nutrition, pp. 187-208 [PC Garnsworthy and DJA Cole, editors]. Nottingham, UK: Nottingham University Press.

Longland AC \& Low AG (1988) The digestion of three sources of dietary fibre by growing pigs. Proceedings of the Nutrition Society 47, 104 Abstr.

Longland AC \& Low AG (1989) Digestibility of diets containing 
molassed sugar beet pulp or plain sugar beet pulp by growing pigs. Animal Feed Science and Technology 23, 67-78.

McDonald M, Edwards RA, Greenhalgh JFD \& Morgan C (1996) Animal Nutrition, 5th ed. Harlow, Essex: Longman Scientific and Technical.

McLean BML, Hyslop JJ, Longland AC, Cuddeford D \& Hollands T (1999) Development of the mobile bag technique to determine the degradation kinetics of purified starch sources in the precaecal segment of the equine digestive tract. Proceedings of the British Society of Animal Science p. 133.

Macheboeuf D, Poncet C, Jestin M \& Martin-Rossett W (1996) Use of a mobile bag technique with caecum fistulated horses as an alternative method for estimating pre-caecal and total tract nitrogen digestibility. In Proceedings of the 47th Annual Meeting of the European Association of Animal Production, Lillehammer, Norway, pp. 296. Rome: EAAP.

Moore-Colyer MJS (2000) Studies on the degradation kinetics of botanically diverse fibrous feeds and their apparent digestibility and rate of passage when fed to ponies. $\mathrm{PhD}$ Thesis, Edinburgh University.

Moore-Colyer MJS, Hyslop JJ, Longland AC \& Cuddeford D (1997) The degradation of organic matter and crude protein of four botanically diverse feedstuffs in the foregut of ponies as measured by the mobile bag technique. Proceedings of the British Society of Animal Science, p. 120.

Moore-Colyer MJS \& Longland ACL (2000) In vivo apparent digestibility of four types of conserved forage by ponies. Animal Science 71, 527-534.

Moore-Colyer MJS, Longland AC, Hyslop J \& Cuddeford D (2000) Intra-caecal fermentation parameters in ponies fed botanically diverse fibre feeds. Animal Feed Science and Technology 84, 183-197.

Morrison IM (1980) Hemicellulose contamination of acid detergent residues and their replacement by cellulose residues in cell wall analysis. Journal of the Science of Food and Agriculture 31, 639-645.

National Research Council (1989) Nutrient Requirements for Horses, 5th ed. Washington, DC: National Academy Press.

Ørskov ER \& McDonald I (1979) The estimation of protein degradability in the rumen from incubated measurements weighted according to rate of passage. Journal of Agricultural Science Cambridge 92, 499-503.

Pagan J (1998) Forages for horses: More than just a filler. In Advances in Equine Nutrition, pp. 13-27 [J Pagan, editor]. Nottingham, UK: Nottingham University Press.

Peloso JG, Schumaker J, McClure SR, Crabill MR, Honselka DJ, Householder DD \& Potter GD (1994) Technique for long term ileal cannulation in ponies. Canadian Journal of Veterinary Research 58, 181-184.

Potter GD, Arnold FF, Householder DD, Hansen DH \& Brown KM (1992) Digestion of starch in the small or large intestine of the equine. Europaische Knoferenz uber die Ernahrung des Pferdes 140-143.
Radicke S, Kienzle E \& Meyer H (1991) Preileal apparent digestibility of oats and corn starch and consequences for caecal metabolism. In Proceedings of the 12th Equine Nutrition and Physiology Symposium, Calgary, Canada, pp. 43-48. Savoy, USA.

Robertson JA \& Eastwood MA (1981) An examination of factors which may affect the water holding capacity of dietary fibre. British Journal of Nutrition 45, 83-95.

Sauer WC, Jorgensen H \& Berzins R (1983) A modified nylon bag technique for determining apparent digestibilities of protein in feedstuffs for pigs. Canadian Journal of Animal Science 63, 233-237.

Smoulders EAA, Steg A \& Hindle VA (1990) Organic matter in horses and its prediction. Netherlands Journal of Agricultural Science 38, 435-447.

Southgate DAT, Hudson GJ \& Englyst H (1978) The analysis of dietary fibre - the choices for the analyst. Journal of the Science of Food and Agriculture 29, 979-988.

Stefánsdóttir GJ (1996) Degradation of fibre-based feedstuffs in the caecum of ponies using the in situ technique. MSc Thesis, University of Wales, Aberystwyth.

Theander O \& Aman P (1979) Studies on dietary fibres. 1. Analysis and chemical characterisation of water soluble and water insoluble dietary fibres. Swedish Journal of Agricultural Research 9, 97-106.

Todd LK, Sauer WC, Christopherson RJ, Coleman RJ \& Caine WR (1995) The effect of feeding different forms of alfalfa on nutrient digestibility and voluntary intake in horses. Journal of Animal Physiology and Animal Nutrition 73, 1-8.

Tomlinson A (1997) Voluntary feed intake and apparent digestibility of grass chaff, and an assessment of the mobile bag technique to study the dynamics of fibre digestion in equids. MSc Thesis, University of Wales, Aberystwyth.

Uden P \& Van Soest PJ (1984) Investigations of the in situ bag technique and a comparison of the fermentation in heifers, sheep, ponies and rabbits. Journal of Animal Science 58, 213-221.

Van Straalen WM, Dooper FMH, Antoniewicz AM, Kosmala I \& Van Vuuren AM (1993) Intestinal digestibility in dairy cows of protein from grass and clover measured with mobile nylon bag and other methods. Journal of Dairy Science 76, 2970-2981.

Varvikko T \& Vanhatalo A (1990) The effect of differing types of cloth and of contamination by non-feed nitrogen on intestinal digestion estimates using porous synthetic-fibre bags in cows. British Journal of Nutrition 63, 221-229.

Van Soest PJ (1994) Nutritional Ecology of the Ruminant, 2nd ed. Ithaca, NY: Comstock Publishing Associates, Cornell University Press.

Yan T, Longland AC, Close WH, Sharpe CE \& Keal HD (1995) The digestion of dry matter and non-starch polysaccharides from diets containing plain sugar beetpulp or wheat straw by pregnant sows. Animal Science 61, 305-309.

Yelle M (1986) Clinicians guide to equine laminitis. Equine Veterinary Journal 18, 156-158. 